Başvuru :08.03.2018

Kabul : :04.04.2019

\title{
Uluslararası Ticarette İşletmeler Arası İlişki Kalitesinin Kavramsallaştırılması ve Tekstil İhracatçıları Üzerine Bir Uygulama ${ }^{1}$
}

\begin{tabular}{l}
\hline Uluslararası Ticarette İşletmeler Arası iliş̧i Kalitesinin \\
Kavramsallaştırılması ve Tekstil Ihracatçıları Üzerine Bir \\
Uygulama \\
Öz
\end{tabular}

$\mathrm{Bu}$ çalışmanın amacı, işletmelerin karşılıklı alışveriş süreçleri sonucunda ortaya çıkan ilişki kalitesi olgusunu uluslararası ticaret bağlamında yeniden kavramsallaştırmaktır. Yazında, ilişki kalitesinin çeşitli biçimlerde tanımlandığı fakat kavramın uluslararası işlemlere özgü yönüyle yeterince ele alınmadığı görülmektedir. Alandaki mevcut bilgiler ışığında yapılan kavramsal çıkarımlar, görgül bir araştırmayla sınanmıştır. Araştırmanın kapsamı, Türkiye'deki ihracatçı firmaların yurtdışındaki müşterileriyle yürüttükleri ticari ilişkilerdir. Çalışmada, nicel ağılıklı bir araştırma tasarımı benimsenmiş; veriler, belirlenen örneklem grubundan anket yoluyla toplanmıştır. 165 gözleme dayalı bulgular, uluslararası ticarette ilişki kalitesinin güven, memnuniyet ve ilişkisel öğrenme boyutlarından oluştuğu yaklaşımını desteklemektedir. Çalışmanın, ilgili yazında nadiren rastlanan ilişkisel öğrenme olgusunun uluslararası ticaretteki önemini vurgulaması açısından alana kuramsal katkı sağlayacağı düşünülmektedir.

Anahtar Kelimeler: Uluslararası Ticaret, İşletmeler Arası İlişkiler, Güven, Memnuniyet, İlişkisel Öğrenme, İlişki Kalitesi
Conceptualizing the Inter-firm Relationship Quality in International Trade and an Application on Textile Exporters

\section{Abstract}

The purpose of this study is to re-conceptualize the relationship quality that occurs in buyer-seller exchanges within the international trade context. In relevant literature, extensive work has been done to define the relationship quality; however its particular aspects pertaining to international transactions require further examination. This study's conceptual inferences, which are derived from the current knowledge, have been tested by an empirical research. The scope of the research is the exchanges between exporting firms in Turkey and their customers abroad. In this respect, a quantitative research design is employed and data is collected from the sample group through a survey. Based on 165 observations, the findings support the approach that relationship quality in international trade is composed of trust, satisfaction, and relational learning dimensions. The research makes a theoretical contribution by highlighting the importance of neglected relational learning concept in inter-firm relationship quality research in the context of international exchanges.

Keywords: International Trade, Inter-firm Relationships, Trust, Satisfaction, Relational Learning, Relationship Quality

\section{Giriş}

İşletmeler arası ilişkiler, yalın ifadeyle, iki veya daha fazla örgüt arasında kurulmuş bağlantılar ve süregiden işlemlerdir (Oliver, 1990:241). İşletmecilik yazınında, zamanla ilişkiye evrilen örgütler arası alışverişler, işbirliğine dayalı işletmeler arası ilişkiler olarak ele alınmaktadır (Ritter ve Gemünden, 2003). İşbirliği, bağımsız aktörlerin belirli çıkar ve amaçları adına, arala-

\footnotetext{
${ }^{1}$ Bu çalışma, İstanbul Üniversitesi, Sosyal Bilimler Enstitüsü, İşletme Yönetimi ve Organizasyon Anabilim Dalında, Prof. Dr. Fatih Semerciöz danışmanlığında, Aytuğ Sözüer tarafından "Uluslararası Ticarette İşletmeler Arası İlişki Kalitesi: Türkiye'deki İhracatçı Firmaların Yurt Dışındaki Müşterileriyle İlişkileri Üzerine Bir Araştırma" ismiyle tamamlanarak 15.06.2016 tarihinde savunulan doktora tezinden türetilmiştir.

2 Dr. Öğr. Üyesi, Yalova Üniversitesi, IỉBF, Uluslararası Ticaret ve Finansman Bölümü, aytug.sozuer@yalova.edu.tr, ORCID: 0000-0003-2680-2071

3 Prof. Dr., İstanbul Üniversitesi, İşletme Fakültesi, İşletme Bölümü fsemerci@istanbul.edu.tr, ORCID: 0000-00026406-8915
} 
rındaki ilişkilerin düzenli işlemesi ve kararların ortaklaşa alınabilmesi için gerekli yapı ve kuralları biçimsel ve biçimsel olmayan görüşmelerle oluşturdukları etkileşim süreci olarak tanımlanmaktadır (Thomson ve Perry, 2006:23). İşbirliğine dayalı işletmeler arası ilişkiler ise, işletmelerin maliyet düşürmek veya değer yaratmak gibi çıkarları adına, zaman içinde kendi aralarında gelişen güçlü ve kapsamlı sosyal, ekonomik ve teknolojik bağları ifade etmektedir (Anderson ve Narus, 1991:96). Diğer yandan, işbirliğine dayalı olsa da, işletmeler arası ilişkiler dikensiz gül bahçesi değildir. İlişkideki taraflar önce kendi çıkarlarını gözettikleri için arada anlaşmazlıkların veya çatışmaların olması doğaldır. Dolayısıyla, ilişkilerin sağlıklı yürümesinin bir maliyeti vardır ve örgütlerin bunun için sermaye, emek ve zaman ayırması gerekmektedir (Anderson vd., 1994). İşletme yöneticilerinin mevcut işbirliklerinin başarı durumunu değerlendirmeleri ve ilişkiye devam edip etmeme kararını verilebilmeleri, işletmeler arası ilişkileri inceleme ihtiyacını ortaya çıkarmaktadır. Bu tip bir değerlendirme, aynı zamanda araştırmacılar için de ticari ilişkileri anlamlı biçimde karşılaştırılabilmeleri veya başarılı işbirliklerinin yapı ve süreçlerini açıklayabilmeleri adına önem taşımaktadır (Provan ve Sydow, 2008).

2000'li yılların başı, uluslararası ticari faaliyetlerde hızlı bir yükselişe sahne olmuştur. 20002016 yılları arasında dünyadaki doğrudan yabancı yatırım stoku, diğer bir ifadeyle özel veya kamu teşebbüslerinin yurt dışında yaptıkları uzun vadeli sermaye yatırımları birikimi, yaklaşık 7,5 trilyon ABD Dolarından 26 trilyon ABD dolarının üzerine çıkmıştır (UNCTAD, 2017). Aynı dönemde, dünyadaki yıllık ihracat hacmi 6,5 trilyon $A B D$ dolarından 16 trilyon $A B D$ dolarına yükselmiştir (TWB, 2017). Bu veriler, bahsedilen faaliyetlerin 17 yılda yaklaşık üç kat arttığına işaret etmektedir.

İşletmeler arası ticari ilişkiler, bahsedildiği şekilde uluslararası özellik kazandığında, işbirliği süreci daha karmaşık hale gelmektedir çünkü mevcut belirsizlik durumuna taraflar ve içinde bulundukları çevreler arasındaki farklar eklenmektedir. İşletmeler arası ilişkilerin uluslararası bağlamı, bu çevrelerin birbirine mesafesinden kaynaklanan unsurları yansıtmaktadır. Ayrıca, ilişki sürecinde işletmeler arasındaki yakınlık-uzaklık, güç-bağımlılık ve karşılıklı beklentileri içine alan bir atmosfer oluşmaktadır (Hakansson, 1982). İlgili yazında, bu atmosferi değerlendirmek için kullanılan kavramlardan biri ilişki kalitesidir (Dwyer ve Oh, 1987).

İşletmeler arası ilişki kalitesi kavramı, taraflar arasındaki ilişkinin genel havasını ve ilişkisel bağlarının gücünü ifade etmektedir (Johnson, 1999; Palmatier; 2008). Aynı zamanda, kavramın çeşitli unsurları kapsadığı kabul edilmektedir. Öte yandan, kavramın hangi boyutlardan oluştuğu; öncelleri ve sonuçlarına ilişkin araştırmalar halen devam etmektedir.

Bu çalışmada, işletmeler arası işbirliklerinin değerlendirilmesinde kullanışlı bir kavram olan ilişki kalitesi ve bunun dinamiklerini daha karmaşık hale getiren uluslararası ticari işlemlerdeki durumu ele alınmıştır. Alan yazınında, uluslararası ticarete özgü bir ilişki kalitesi var mıdır sorusuna kesin bir cevabın bulunmamasından hareket eden bu araştırmayla, ülkeler ve işletmeler arasındaki mesafe olgusunun ilişki sürecindeki rolüne dair tartışmalara katkı sağlanması amaçlanmıştır.

Ilerleyen bölümlerde, öncelikle ilişki kalitesine dair alandaki bilgi ve yaklaşımlar aktarılacak; ardından uluslararası ticarete özgü olan ilişki kalitesi olgusu kavramsallaştırılacak ve bunu sınayan bir görgül araştırma açıklandıktan sonra bulgular tartışılacaktır. 


\section{Yazın İncelemesi}

İşletme yönetimi yazınında 1990'larda yaygınlaşmaya başlamış olan ilişki kalitesi kavramı, iktisadi ilişkilerdeki genel hali tespit etmeyi amaçlamaktadır. iliş̧ki kalitesi; kişiler arası, işletme ile çalışanları arası, işletme ile müşterileri arası veya örgütler arası gibi farklı düzeylerde incelenebilmektedir. Öte yandan, literatürde kavramın tanımı, boyutları, belirleyicileri ve sonuçları üzerinde fikir çeşitliliği bulunmaktadır.

İlişki kalitesinin ilgili yazında nasıl kavramsallaştırıldığını anlamak ve öncelikle olgunun biçimsel tanımlarını tespit etmek adına bir inceleme yapılmıştır. Bunun için, uluslararası alan endekslerinde ve veri tabanlarında yer alan akademik eserler, başlıkları ve anahtar kelimeleri üzerinden taranmıştır. Kavramın tanımlarını ve boyutlarını içeren eserleri belirlerken, ilişki kalitesi ifadesini birebir kullanan çalışmalar seçilmiştir.

Iliş̧ki kalitesi kavramına dair özgün tanım içeren 28 çalışma incelendiğinde (kavramı sadece alt boyutlarıyla tanımlayanlar hariç), dikkat çeken ve öne çıkan bazı özellikler bulunmaktadır. Geniş kapsamda, ilişki kalitesiyle, ilişki halindeki taraflar arasında genel bir olumluluk halinin varlığı ve bu ilişkiyi uzun vadede uyum içinde sürdürme niyetinin yansıtılmaya çalışıldığı anlaşılmaktadır (ör. Fynes vd., 2004:182; Hennig-Thurau vd., 2002:234; Hutchinson vd., 2011: 467; Ivens ve Pardo, 2007:473; Jap vd., 1999:304; Lahiri ve Kedia, 2011: 12; Marquardt, 2013:1390; Skarmeas ve Robson, 2008: 172; Terawatanavong vd., 2011:912; Venkatesh ve Bala, 2012:10). Ayrıca, ilişki içinde etkin bir çalışma ortamı yaratılmasında, taraflar arasındaki bağlantıların niteliği ve amaçlara uygunluğu da sıkça bahsedilen bir olgudur (ör. Chinomona, 2013:45; Huntley, 2006:706; Leonidou vd., 2006:578; Moorman vd., 1992: 316). Bunlarla beraber, mevcut ilişkilerin değerlendirilmesinde ve karşılıklı beklentilerin oluşmasında, geçmiş deneyimlerin önemi de vurgulanmaktadır (ör. Crosby vd., 1990:70; Holmlund, 2008: 35; Smith, 1998: 78).

ilişkiye dair pek çok özelliğin atfedildiği ilişki kalitesinin, çeşitli boyutlardan meydana gelen bir üst kavram (İngilizcede higher-order construct) olduğu da çoğu eserde yer almaktadır. 1995-2015 yılları arasında, ilişki kalitesini işleyen 86 çalışmanın 76'sında kavram çok boyutlu olarak ele alınmıştır. Öte yandan, bu boyutlar hakkında dikkate değer bir çeşitlilik bulunmaktadır. En sık kullanılan boyutların; güven (61 çalışmada), bağııık (46 çalışmada) ve memnuniyet (42 çalışmada) olduğu tespit edilmiştir. Diğer boyutlardan öne çıkanlar ise; iletişim, işbirliği, uyum ve çatışmasızlıktır (Sözüer, 2016).

İlişki kalitesini uluslararası ticaret kapsamında inceleyen çalışmalara bakıldığında ise (Ahamed ve Skallerud, 2013; Barry ve Doney, 2011; Hoppner vd., 2015; Lages vd., 2005; Leonidou vd., 2006; Nguyen ve Nguyen, 2010; Ural, 2009; Velez vd., 2015), kavramı oluşturan boyutların ve bunları etkileyecek uluslararası alışverişlere özgü koşulların itina ile tanımlanmasına rağmen, ilişki kalitesinin kavramsallaştırılması için özel bir yaklaşım sergilenmediği görülmektedir. Sadece Skarmeas ve meslektaşları (2008) ile Skarmeas ve Robson'un (2008) çalışmalarında, açıklanan boyutların (güven, bağııık, memnuniyet ve çatışmasızlık) işletmelerde ithalat yöneticileriyle yapılan mülakatlara dayanarak seçildiği ifade edilmiştir. Yazında mevcut bu sınırlı bilgi sebebiyle, uluslararası ticarette ilişki kalitesi olgusunun daha derinlemesine incelenmesi makul hale gelmektedir. 


\section{Uluslararası Ticarette İlişki Kalitesinin Kavramsallaştırılması}

Örgütlerin karşı karşıya kaldıkları sorunları tanımlama, değerlendirme ve çözme eylemleri onların kültürlerini belirlemektedir (Levinson ve Asahi, 1995). Bir yandan da bu kültür, örgütlerin çevresindeki değerler, ilkeler, bilgiler, inançlar, paradigmalardan etkilenmekte ve bu sayede meşruiyet kazanmaktadır (Ahmed vd., 1999). Örgütlerin kendi tarihi ile kurumsal ve kültürel ortamlarının etkileşimi sonucu yerleşen bu davranış kalıpları, kendisi ve yakın çevresine has özellikler göstermekte ve uzak çevresindeki yapılardan ayrışmaktadır (Collis, 1991). Dolayısıyla, örgütlerin yerleşik oldukları ortamlar arasına mesafe girdikçe, örgütlerin tipik işlevlerinin ve bakış açılarının da birbirinden farklılaşması beklenmektedir. Bu yüzden, uluslararası ticarette ilişki kalitesi münhasıran irdelenebilecek bir konudur.

Uluslararası ortamda gerçekleşen işletmeler arası alışverişler, yurtiçindekilere kıyasla doğal olarak bazı farklılıklar göstermektedir. Burkert vd. (2012) bunları: (a) Alıcı ve satıcı arasındaki temastaki sıklık ve yoğunluğun düşük olması, (b) Taraflar arasındaki sosyal mesafenin fazla olması, (c) iliş̧kiye bağlanma ve yatırım yapma isteğinin az olması ve (d) Ortalama ilişki sürelerinin kısa olması şeklinde tespit etmektedir.

Bu çalışmada, gerek yazındaki kavramsallaştırmalar gerekse uluslararası ticaret bağlamı dikkate alındığında, ilişki kalitesinin; ilişkide yaşanan sürtüşmenin az, ilişkiden sağlanan faydanın çok olduğuna dair algının derecesi biçiminde tanımlanması uygun görülmektedir. Bu tip bir tanımın, yazında vurgulandığı üzere, ilişki hakkındaki genel değerlendirmeyi yansıtacağı düşünülmektedir. Kavramı oluşturan boyutların da güven, memnuniyet ve ilişkisel öğrenme olacağı varsayılmıştır. Bu kavramsallaştırmada, ilişki kalitesinin güven boyutunun sürtüşmesizlik, memnuniyet ve ilişkisel öğrenme boyutlarının da fayda unsurlarını yansıtacağı öngörülmektedir. Güven ve memnuniyet, ilişki kalitesi yazınında en çok kullanılan boyutlar olmakla beraber, ilişkisel öğrenme kavramına ender rastlanmaktadır. Halbuki, ilişkisel öğrenme uluslararası ticari ilişkilerin belirgin bir çıktısıdır ve ilişki kalitesinin boyutu olarak değerlendirilmelidir (Raskovic vd., 2013).

Bu tanımlamanın ardından, bahsedilen kavramların detaylı incelemesine geçilecektir.

\subsection{Güven}

Baier'in (1985:235) güven tanımı, ötekinden beklenmese bile, bir kötü niyet (veya iyi niyet eksikliği) intimaline karşı zafiyetin kabullenilmesi şeklindedir. Bu tanımlama iki husus içermektedir. Birincisi, güvenin, karşı tarafın tahmin edilirliğine ilişkin inanç, duygu veya beklenti olarak görülmesidir. İkincisi, güvenen tarafta bir zafiyet ve ortamda bir belirsizlik olmasına rağmen, ötekine duyulan itimadı yansıtmaktadır. Bu noktada, zafiyet ve belirsizlik durumlarının altı çizilmekte; bunlar yok ise güven meselesinden bahsetmenin yersiz olduğu belirtilmektedir (Moorman vd., 1992).

Adler (2001) güven olgusunun genel bir çerçevesini çizerek, bunun kaynakları, mekanizmaları, nesneleri ve özellikleri bakımından incelenebileceğini ifade etmektedir. Ona göre güvenin üç kaynağı bulunmaktadır: (a) Önceki etkileşimlerin deneyimiyle oluşmuş güven (veya güvensizlik), (b) Karşı tarafın suistimalinin yine kendisini zararlı çıkaracağını düşündüren hesapçı güven ve (c) Yerleşik değer ve kurallara dayalı güven. Bunların yanında, güveni yaratan mekanizmaların; kişiler arası doğrudan temas, tanıdık güvenilir tarafların tavsiyesi ve karşı tarafın değer ve davranışlarını belirlediği düşünülen kurumsal ortam olduğu belirtilmektedir. Güveni oluşturan bu kaynaklar ve mekanizmaların kendi içlerinde birbirini tamamlayıcı özellik gösterdiği de ifade edilmektedir. Adler (2001:217-218) ayrıca, güvenin yöneldiği nesneleri kişiler, 
sistemler ve gruplar biçiminde ayırmakta; güvenin dayanaklarını ise istikrar, yetkinlik, iyi niyet, sadakat, dürüstlük, samimiyet, açıklık ve benzer nitelikler şeklinde tanımlamaktadır. Zucker (1986) ise, güvenin dayanaklarını daha yalın bir perspektifle ele almaktadır. Ona göre, tarafların beklentilerini belirleyen güvenin üç türü vardır: (a) Tekrarlanan işlemlerden kaynaklanan süreç temelli güven, (b) Sosyal yönden benzerliğe dayanan özellik temelli güven ve (c) Toplumdaki biçimsel yapılara bağlı kurumsal temelli güven. Zucker bu türlerin kısmen birbirini ikame edebileceğini de belirtmektedir (s.65).

Güven, gerçek kişilere dair bir olgu olsa da örgütler arası ilişkiler açısından da değerlendirilebilmektedir çünkü bu ilişkiler zaten örgüt üyesi kişiler tarafından yürütülmektedir (Aulakh vd., 1996; Gulati ve Singh, 1998). Bu kapsamda, Zaheer, McEvily ve Perrone (1998) kişiler arası ve örgütler arası düzeylerde güvenden bahsetmektedir. Bunların ilki, karşılıklı temasta bulunan örgüt üyelerinin birbirine duyduğu güvendir. İkincisi ise örgüt üyelerinin -kolektif biçimdeilişkide oldukları örgüte duydukları güven şeklinde tanımlanmaktadır. Öte yandan, Lane ve Bachmann (1996) örgütler arası ilişkiler gibi nispeten karmaşık süreçlerde, güvenin kişilerin durumsal tercihlerinden daha çok, tarafların yerleşik oldukları kurumsal ortama dayandığını saptamaktadır.

Örgütler arası ilişkilerde güvene dair diğer konu, ilişkilerde bulunan risk ve belirsizliktir. Humphrey ve Schmitz (1998) işletmeler arası ticari işlemlerde riske karşı iki yolun, yaptırım ve güven olduğunu belirtmektedir. Illk yolda, karşı tarafın fırsatçı olduğu, diğer bir ifadeyle kendi çıkarı için hilekârlık yapabileceği varsayımından (Williamson, 1979) hareket edilmektedir. Bu yüzden sözleşmelerde yükümlülüklere ilişkin teşvik edici veya caydırıcı maddeler konulmakta; bu sayede anlaşmaya aykırı davranmanın önü kesilmeye çalışımaktadır. Bu güvenin hesaplanabilir olduğuna dönük yaklaşımdır. İkinci yol ise, karşı tarafın iyi niyetine güvenmeyi, bilinçli şekilde tercih etmekten geçmektedir (Ring ve Van de Ven, 1992). Bu da güvende hesaplanamazlık unsuruna dayanmaktadır (Gulati ve Sytch, 2008). Bahsedilen ikinci yol, özellikle işletmeler arası ilişkilerin birbiriyle bağlantılı olduğu şebeke yapılarda gözlenmektedir (Oba ve Semerciöz, 2005).

Güven, piyasa ve hiyerarşi mekanizmalarının dışında bir işletmeler arası ilişki yönetimi unsuru olarak da kabul edilmektedir (Bradach ve Eccles, 1989). Güven, alışverişte karşı tarafın fırsatçı davranacağına dair kuşkuyu azaltan bir beklentidir. Bu sayede, bir sosyal mekanizma olarak güven, işlemlerde denetim ihtiyacını azaltarak, ilişkinin verimliliğini artırmaktadır (Madhok, 1995). Hatta güven olgusunun, geleneksel ticari işlemlerde biçimsel sözleşmelerden daha belirgin bir işlevi olduğu vurgulanmaktadır (Macaulay, 1963).

Uluslararası ticaret kapsamında işletmeler arası güven, doğası itibariyle ülkeler arasında farklıık gösterebilmektedir (Zaheer ve Zaheer, 2006). Ülkelerin farklı kültürleri, değer sistemleri ve kurumları, o bağlamdaki örgütlerde bulunan güven yapısını etkilemektedir (Arino vd., 001). Hatta Fukuyama (1995) ülkeler arası sosyal ve iktisadi gelişmişlik farklarını güven olgusu üzerinden açıklamaktadır. Dolayısıyla, ayrı ulusal bağlamlarda bulunan işletmelerin aralarındaki ilişkiler değerlen-dirilirken, güven kavramına özenli yaklaşılması gerektiği vurgulanmaktadır (Bachman ve Zaheer, 2008).

Örgütler arası ilişkilerde güvenin yararlarını araştıran çalışmalar, kavramın müzakere maliyetleri, çatışma, bilgi paylaşımı, işbirliği ve örgütsel performansla ilişkilerini tespit etmektedir (Gulati ve Sytch, 2008). Ayrıca güven, uzun vadeli ilişkilerin gelişiminde önemli rol oynamaktadır (Anderson ve Weitz, 1989). Ganesan (1994:3) bunun nedenlerini; (a) Karşı tarafın fırsatçılığına bağlı risk algısının azalması, (b) Kısa vadedeki eşitsizliklerin uzun dönemde çözüleceğine 
inanılması ve (c) Alışverişte işlem maliyetlerinin düşmesi olarak özetlemektedir. Öte yandan, güven eksikliği taraflar arasında olumsuz tavır, davranış ve iletişim sorunlarına neden olarak işbirliğinde verimsizliğe yol açmaktadır (Dwyer vd., 1987).

İşletmeler arası güven, tarafların birbirinin izlediği kurallar ve usulleri fark etmesine yardımcı olmakta ve karşıııkı anlayışı sağlamaktadır (Gulati ve Singh, 1998). Bu yüzden Arrow (1974:23) güveni, sosyal sistemlerde bir kayganlaştırıcı olarak tanımlamaktadır. Bu bakış açısıyla, işletmeler arası ilişkilerde güvenin sürtüşmesizlik unsurunu yansıttığı yaklaşımı örtüşmektedir.

İşletmeler arası güven yazını incelendiğinde, kavramın çok boyutlu ve çok katmanlı olduğu görülmektedir (Semerciöz, 2000). Güven değişkeninin, işletmeler arası ilişki kalitesinin bir boyutu olarak ele alındığı bu çalışmada, kavram öz bir kapsamda değerlendirilecektir. Bu yüzden, Schurr ve Ozanne'nin (1985:940) benimsediği; bir alışverişte karşı tarafın sözünün muteber olduğu ve yükümlülüklerini gerçekleştireceğine dair inanç biçimindeki tanım tercih edilecektir. Böylece güvenin, çeşitli ulusal bağlamlardaki anlam farklarının doğuracağı sakıncalardan da kaçınılacağı düşünülmektedir.

\subsection{Memnuniyet}

Anderson ve Narus (1984:66) memnuniyeti, bir işletmenin diğeriyle yürüttüğü ilişkiyi tüm yönleriyle değerlendirmesi sonucunda ortaya çıkan duygusal bir olumluluk hali şeklinde tanımlamaktadır. Bu yönüyle memnuniyet, geçmişteki olayların olumlu veya olumsuz biçimde yorumlanmasıyla ilgilidir (Ivens ve Pardo, 2007). Diğer bir açıdan, alışverişteki tarafların birbirlerinden beklentileri ile ortaya çıkan sonuçlar karşılaştırıldığında, aradaki fark, memnuniyeti yansıtmaktadır (Wilson, 1995). Bu perspektif, yazındaki uyumsuzluk paradigmasından (Oliver, 1980) gelmektedir. Paradigmaya göre tüketici memnuniyeti, bir alışverişten beklenti ile algılanan performansın kıyaslanmasıyla ortaya çıkmaktadır. Eğer algılanan performans beklentiyle uyumluysa müşteri memnun, beklentiyi aşıyorsa çok memnun (pozitif uyumsuzluk), beklentinin altında kalıyorsa memnuniyetsiz (negatif uyumsuzluk) olmaktadır (Ulaga ve Eggert, 2006). Böylece memnuniyetin, esasta, zihinsel bir süreç ve duygusal bir tepki olduğu anlaşılmaktadır (Hennig-Thurau vd., 2002).

Geyskens, Steenkamp ve Kumar (1999) memnuniyet kavramının ekonomik ve sosyal yönleri bulunduğunu belirtmektedir. Ekonomik memnuniyet, bir ilişkideki tarafların iktisadi kazanımları sonucu oluşan olumlu durumu ifade etmektedir. Iliş̧kiden memnun olanlar, ilişki sayesinde iktisadi amaçlarını gerçekleştirdiğini düşünmektedir. Tarafları memnun eden ilişkinin genel etkinliği, üretkenliği ve finansal sonuçlarıdır. Sosyal memnuniyet ise; ilişkinin psikososyal unsurlarından, alışverişin tatmin edici ve zahmetsiz oluşundan kaynaklanmaktadır (Geyskens ve Steenkamp, 2000). Bu kapsamda, taraflar birbiriyle irtibatta olmaktan memnundur ve kişisel düzeydeki ilgi, saygı ve bilgi paylaşımını önemsemektedir.

Ivens ve Pardo (2007) işletmeler arası memnuniyetin, alışverişin işlemsel veya ilişkisel oluşuna göre de değiştiğini vurgulamaktadır. Tek bir işleme kıyasla, yürüyen bir ilişkinin değerlendirilmesi daha karmaşık olmaktadır. Sürekli bir ilişkide farklı temas düzeyleri ve ilişki safhaları bulunmaktadır. Bu yüzden, kısmen çelişik pek çok unsuru barındıran uzun süreli ilişkilerde, memnuniyet yargısı değişkenlik gösterebilmektedir.

Işletmeler arası ilişkilerde memnuniyetin, işbirliğini artırıcı bir işlev gördüğü de kabul edilmektedir (Bruggen vd., 2005). Karşlıklı memnuniyet, ilişkideki belirsizliği azaltmakta ve işlemlerin devamına imkân sağlamaktadır (Nyaga ve Whipple, 2011). Bu yüzden, ilişkideki beklenti- 
lerin karşılanması veya aşılmasını yansıtan memnuniyetin, işletmeler arası ilişki kalitesinin önemli bir unsuru olduğu ifade edilmektedir (Lages vd., 2005). Illgili araştırmalar, kaliteli ilişkilerde tarafların memnuniyet düzeyinin de yüksek olduğunu ortaya koymaktadır (Dorsch vd., 1998). Keza, yazın incelemesi de göstermektedir ki, memnuniyet, ilişki kalitesinin tespitinde en sık kullanılan üç değişkenden biridir.

Bu çalışma kapsamında, memnuniyet kavramının süregiden bir ilişkideki duygusal olumluluk hali (Anderson ve Narus, 1984:66) tanımıyla ilişki kalitesindeki fayda unsurunu kısmen yansıtacağı düşünülmektedir. Uluslararası ticaret bağlamında, fayda unsurunun diğer parçasını ise, ilişkisel öğrenme olgusunun belirleyeceği öngörülmektedir.

\section{3. İlişkisel Öğrenme}

Levitt ve March (1988:320) örgütsel öğrenmeyi, örgütün kendisinin ve diğerlerinin deneyimlerinden çıkarımlar yaparak, bunları gelecekteki davranışlarına yön verecek rutinlere dönüştürmesi biçiminde tanımlanmaktadır. Buna paralel şekilde, Nonaka (1994:27) da örgütün çevresiyle ilişkisinin sürekli bir öğrenme kaynağı olduğunu vurgulamaktadır.

Hakansson, Havila ve Pedersen (1999:443) diğer örgütlerden öğrenmenin ya bilginin bir taraftan ötekine doğrudan aktarımı ya da ötekinin süreç ve çıktılarında beliren bilginin gözlem yoluyla edinilmesiyle gerçekleştiğini belirtmektedir. Dyer ve Singh (1998:665), işletmeler arası ilişkilere dayalı öğrenmenin, alışveriş halindeki taraflarca yaratılan veya yeniden biçimlenen uzmanlık bilgisinin paylaşımıyla ortaya çıktığını ifade etmektedir. Capon ve Glazer (1987:2) da bu uzmanlık bilgisinin bileşenlerini; ürün (fikirlerin somutlaşmış hali), süreç (üretim ve dağıtım yöntemleri) ile yönetim (işletme idaresi ve pazarlama yöntemleri) bilgisi olarak tanımlamaktadır.

ilişkisel öğrenme kavramını öne çıkaran Selnes ve Sallis (2003), kavramı, bir alışverişteki taraflar arasında paylaşılan bilginin benzer şekilde yorumlanarak ilişkiye özgü hafızaya yerleşmesi ve bunun ilişki kapsamındaki davranışları etkilemesi olarak tanımlamakta; ilişkisel öğrenme sürecinin ortaklaşa yürütülen bir eylem olduğunu vurgulamaktadır. Yazarlar, ilişkisel öğrenmeyi örgütsel öğrenme kavramından da üç bakımdan ayırmaktadır. Birincisi, ilişkisel hafıza örgütsel hafızadan farklıdır çünkü ilişkide salt bir tarafa ait olmayan, ortak geçmişle oluşmuş değer ve anlamlar bulunmaktadır. İkincisi, ilişkisel öğrenmenin gerçekleşmesi için tek bir tarafın niyeti veya becerisi yeterli değildir; iki tarafın işbirliği gereklidir. Üçüncüsü, ilişkisel öğrenme ile örgütsel öğrenmenin sonuçları farklıdır çünkü ilkinde öğrenme süreci çok taraflıdır ve bu yüzden etkileri daha kapsamlı olmaktadır. Diğer yandan, Azdegan ve meslektaşları (2008:20), işletmeler arası öğrenmede, tarafların nasıl ve ne kadar öğrendiği konularının da önemli olduğunu belirtmektedir.

Jean, Sinkovics ve Kim (2010) uluslararası ticaret bağlamında yaptıkları bir çalışmada ilişkisel öğrenmeyi, müşteri ile tedarikçi arasındaki iletişim aracılığıyla uzmanlık bilgisinin paylaşımı, operasyonel ve stratejik meselelerin analizi ve sorunların çözümü için sarf ettikleri ortak çaba biçiminde tanımlamaktadır. Bu tanımda, öğrenmeye ilişkin bilgi paylaşımının ötesinde, işletmeler arası işbirliğine vurgu yapıldığı görülmektedir.

İşletmeler arası bilgi paylaşımını ilişki kalitesinin bir boyutu olarak ele alan çalışmalar bulunmasına rağmen (ör. Cater ve Cater, 2010; Chang vd., 2012; Mysen vd., 2012), ilişkisel öğrenme boyutunu içeren yazın çok sınırlıdır. Raskovic ve meslektaşları (2013), benzerinin daha önce yapılmadığını öne sürdükleri araştırmalarında, çokuluslu işletmelerin küresel alışverişleri kapsamında, ilişkisel öğrenmeyi ilişki kalitesinin bir boyutu olarak test etmiş ve anlamlı sonuç 
bulmuştur. Bunun yanında, çeşitli araştırmalar ilişkisel öğrenmenin işlem maliyetlerini düşürürken, üretkenliği ve kaliteyi yükselttiğini göstermektedir (Kohtamaki ve Bourlakis, 2012). Bu faydalar sayesinde alışverişin tatmin edici olması ve taraflar arasındaki bağların güçlenmesiyle ilişki kalitesinin artması beklenen bir sonuç haline gelmektedir.

ilişkisel öğrenmenin işletmeler arası ilişki kalitesinin bir boyutu olarak değerlendirildiği bu çalışma kapsamında kavram, Dyer ve Singh'in (1998) yaklaşımıyla, süregiden bir alışverişte taraflardan birinin diğerinden uzmanlık bilgisi edinmesi şeklinde ele alınacaktır. Uluslararası ticarette ortaya çıkan örgütsel farklılıkların bir öğrenme kaynağı olduğu varsayımının (Nooteboom, 2008) da bu bakış açısını desteklediği düşünülmektedir.

Bu bölümden sonra, uluslararası ticarette işletmeler arası ilişki kalitesine dair yapılan özgün kavramsallaştırmayı sınayan görgül araştırma açıklanacaktır.

\section{Araştırma Yöntemi}

\section{1. Örneklem seçimi}

2014 yılı verilerine göre Türkiye' de yaklaşık 63.000 işletme ihracat gerçekleştirmiştir (Tüik, 2015). Bu işletmeler 26 endüstriyel sektör içinde sınıflandırılmaktadır. Bunlar arasından, örneklem için iradi biçimde tek bir sektöre odaklanılması planlanmıştır. Böylece, işlemlere konu olan ürün ve hizmetler ile sektörlere dair yapısal farklılıkların, ele alınan değişkenler üzerindeki etkisinin asgariye çekileceği varsayılmıştır. Sektör seçimi için yine iradi bir prosedür izlenmiştir. Belirlenecek sektörün mümkün olduğunca rekabetçi bir yapıya sahip olması tercih edilmiştir. Bu sayede, incelenen kavramlar açısından, gözlemlere göre değişkenliğin daha çok bulunacağı öngörülmüştür.

Sektörün rekabetçiliğini yansıtacak üç kriter belirlenmiştir. Bunlar; (a) Sektör ihracatının toplam ihracat içindeki payı, (b) Sektördeki ihracatçı işletme sayısı ve (c) Sektörün ihracat satış konsantrasyon oranıdır. Bu kriterlerin, sektörün genel anlamda ihracat yapabilme kapasitesini, sektöre girişlerin kolaylığını ve sektör ihracatının az sayıda işletmenin hâkimiyetinde olmadığını yansıtacağı varsayılmıştır.

ihracat satış konsantrasyon oranı, iktisadi araştırmalarda kullanılan sektör konsantrasyonu parametresinden uyarlanmıştır. Bu ölçü, bir sektörde en fazla üretim yapan ilk dört, sekiz, yirmi veya elli işletmenin toplam üretim içindeki payını göstermektedir (USCB, 2013). Daha yüksek konsantrasyon oranı, sektördeki belirli sayıda işletmenin baskın olduğunun işaretidir. Bu çalışma için sektörde en fazla ihracat yapan ilk dört işletmenin sektörün toplam ihracatı içindeki payı, ihracat satış konsantrasyon oranı olarak ele alınmıştır.

Sektörlere ilişkin bu kriterlerin hesaplanmasında Türkiye ìhracatçılar Meclisinin hazırladığı "Türkiye'nin Illk 1000 ihracatçı Firması 2014" listesi temel alınmıştır. Bu listedeki firmalar, aynı yıl ülke ihracatının \%58,8'ini gerçekleştirmiştir (TiM, 2015).

Listedeki sektörler;

(1) Sektör ihracatının toplam ihracat içindeki payına göre yukarıdan aşağıya,

(2) Sektördeki ihracatçı işletme sayısına göre yukarıdan aşağıya ve

(3) Sektörün ihracat satış konsantrasyon oranına göre aşağıdan yukarıya sıralanmıştır.

Üç kritere göre en üstte bulunan sektörün en rekabetçi olduğu kabul edilmiştir. Sonuçta, alan araştırmasının hazır giyim ve konfeksiyon sektöründe gerçekleştirilmesine karar verilmiştir. 
Türkiye'de mevzuat gereği, ihracat yapacak gerçek veya tüzel kişilerin, ilgili sektördeki bir ihracatçı birliğine üye olmaları zorunludur. Yapılan çevrimiçi tarama sonucunda, Türkiye'de hazır giyim ve konfeksiyon sektörüne odaklanmış dört ihracatçı birliği tespit edilmiştir. Çalışmada araştırılan değişkenler üzerinde bölgesel farklııkların olası etkilerini azaltmak amacıyla belirli bir ihracatçı birliğine odaklanılması tercih edilmiştir. Bunun da en yüksek üye sayısı ve ihracat hacmine sahip İstanbul Hazır Giyim ve Konfeksiyon ihracatçıları Birliği (IHKiB) olmasına karar verilmiştir.

Son aşamada, İHKiB'e bağı 6.570 üye içinden 2014 yılında en fazla ihracat yapan 1.000 işletmenin örneklem grubunu oluşturması tercih edilmiştir. Bu seviyenin, bir yandan araştırma için yeterli katılım oranını sağlayacağı, diğer yandan da nispeten belirgin hacimde ihracat faaliyetinde bulunan işletmeleri kapsayacağı varsayılmıştır.

\section{2. Ölçekler}

Araştırma değişkenlerini ölçeklendirme sürecinin ilk aşamasında, kavramların Türkiye'deki ihracatçı işletmelere yansımasını anlayabilmek adına, Uludağ İhracatçı Birlikleri bünyesinde gerçekleştirilen bir dış ticaret eğitim seminerine katılan, çeşitli işletmelerin ihracat pazarlama yetkililerine yarı yapılandırılmış anket uygulanmıştır. Bu ankette, yetkililerden örnek olarak birer uzak ve yakın ihracat müşterisi belirlemeleri istenmiş ve bu müşterileriyle olan ilişkileri arasındaki farklııkların muhtemel sebepleri sorulmuştur. Anketten elde edilen veriler, değişkenleri ölçmek için uluslararası yazında daha önce kullanılmış, geçerli ve güvenilir kabul edilen soru ifadelerinin derlenmesine katkı sağlamıştır. Güven ölçeği Cambra-Fierro ve Polo-Redondo (2008) ile Leonidou vd. (2013); memnuniyet ölçeği Cambra-Fierro ve Polo-Redondo (2008) ile Kang, Oh ve Sivadas (2013); ilişkisel öğrenme ölçeği de Ambos ve Ambos'un (2009) çalışmalarından 5'li Likert tipi ölçek olarak uyarlanmıştır. Sonraki aşamada, bu derlenen ifadeler İngilizceden Türkçeye çevrilmiştir. Tercüme ifadelerin anlaşılırlığı ve akıcılığı, yönetim ve organizasyon alanındaki dört doktora öğrencisi tarafından denetlenmiştir. Ardından, ifadeler, uluslararası pazarlama alanından iki ve yönetim-organizasyon alanından beş öğretim üyesi tarafından incelenmiş ve önerilere göre güncellenmiştir. Son olarak, ortaya çıkan soru formu, dış ticaret alanında çalışan üç profesyonel yöneticiyle paylaşılmış ve formun pratikte uygulanabilirliğine dair olumlu görüş alınmıştır. Aşağıdaki ifadeler, anketin ilişki kalitesini ölçen kesitidir.

Müşterimiz güvenilir bir işletmedir. (Güven1)

Müşterimiz bize verdiği sözleri her zaman tutar. (Güven2)

Müşterimiz bize karşı hiçbir zaman fırsatçı davranmaz. (Güven3)

Müşterimiz bize karşı dürüsttür. (Güven4)

Müşterimizin iş yapmak için iyi bir işletme olduğunu düşünürüz. (Memnun1)

İdeal bir ticari işbirliği düşündüğümüzde, bu müşterimizle ilişkimiz iyi seviyededir. (Memnun2)

Genel olarak bu müşterimizle ilişkimizden memnunuz. (Memnun3)

Bu müşterimizle ilişkimiz sayesinde öğrendiklerimiz...

Ürünlerimizin kalitesini artırmamızda faydalı olmaktadır. (Öğrenme1)

Yeni ürünler geliştirmemizde faydalı olmaktadır. (Öğrenme2)

Pazarlama yöntemlerimizi geliştirmemizde faydalı olmaktadır. (Öğrenme3)

Tedarik zinciri uygulamalarını iyileştirmemizde faydalı olmaktadır. (Öğrenme4)

Finansman yöntemleri konusunda faydalı olmaktadır. (Öğrenme5) 


\subsection{Verilerin toplanması}

Örneklem grubu olarak belirlenen ЇКіB üyesi ve 2014 yılında en fazla ihracat yapan 1.000 işletmenin adres ve iletişim listesi IHKIB'den temin edilmiştir. İşletmelerde, ihracat satış yetkilisi veya muadil pozisyondaki bir sorumlunun, cevaplayıcı olmasına dikkat edilmiştir. Bu pozisyonlarda çalışanların, yurtdışı müşterilerle ilişkileri en yakından değerlendirebilecek konumda olduğu varsayılmıştır.

İşletmelerle öncelikle profesyonel bir çağrı merkezi aracılığıyla irtibat kurulmuştur. Telefon çağrılarında, araştırmayla ilgili ön bilgi verilmiş ve ihracat satış yetkilisi veya muadil pozisyondakilere birebir ulaşılmaya çalışılmıştır. Yetkili çalışanlara ulaşıldığı durumlarda, araştırma hakkında kısa açıklama yapılmış ve çalışmaya katılmaya istekli olmaları halinde e-posta adresleri talep edilmiştir. İlgili kişilere ulaşılamadığı durumlarda, e-posta adresleri işletmenin santral biriminden temin edilmeye çalışıımıştır. Toplam 2.464 çağrı sonunda 598 e-posta adresi elde edilmiştir. Çağrı süreciyle eşzamanlı olarak, işletmelerdeki yetkililere soru formunun çevrimiçi bağlantısını içeren e-postalar araştırmacılar tarafından gönderilmiştir. Illk dalga talepler sonucunda, ankete katılan sayısı 120 olmuştur. Bunun ardından, ikinci dalga hatırlatma mesajları gönderilmiş ve toplam cevaplanan anket sayısı 179'a ulaşmıştır.

Araştırmaya katılan 179 işletmeden 9'unun sadece bir ülkeye ihracat yaptığı, 5'inin ise bir yıl veya daha az süredir ankete konu olan müşterileriyle ilişkide olduğu tespit edilmiştir. Bu özelliklerin, araştırma modelinin varsayımlarıyla örtüşmeyeceği yargısıyla, bahsedilen 14 işletme verisinin kullanılmamasına karar verilmiştir. Böylece, analizlerin yapılacağı veri seti 165 işletmeden oluşmuştur. Sonuçta, araştırmaya dönüş oranı \%29,9 (179/598), etkin dönüş oranı ise \%27,6 (165/598) olarak gerçekleşmiştir. Bu oran, uluslararası alım-satım ilişkileri üzerine yapılan araştırmalarda kabul edilen seviyenin üzerindedir (ör. Johnston vd., 2012; Leonidou vd., 2011; Nevins ve Money, 2008; Wu vd., 2007 çalışmalarında bahsedilen oran \%15-\%20 aralığındadır).

Araştırmaya katılan çalışanların, kurum içindeki hiyerarşik pozisyonları açısından, 30'unun (\%18) başkan, genel müdür veya dengi; 87 'sinin (\%53) belirtilen en üst düzey yöneticiye doğrudan rapor veren yönetici; 48'inin de (\%29) bahsedilen bir üst düzey yöneticiye rapor veren yetkili konumunda olduğu anlaşılmıştır.

\section{Bulgular}

\section{1. Örnekleme ilişkin Tanımlayıcı Bilgiler}

Örneklem grubundaki işletmelerin faaliyet türlerine bakıldığında, ağırlıklı olarak hem imalat hem ihracat yaptıkları görülmektedir. 165 işletmenin 132'si üretici-ihracatçı; 25'i ihracatçı; 4'ü belirli bir işletmeler grubunun dış ticaret işlemlerinin yürüten grup dış ticaret firması ve yine 4 'ü sektördeki çeşitli işletmelerin bir araya gelerek oluşturduğu, ihracat faaliyetlerinin ortak bir merkezden yürütülmesini sağlayan sektörel dış ticaret firmasıdır (Tablo 1). İşletmelerin büyük oranda imalatçı olması, örneklemin derinliğini artıran bir unsur olarak görülebilir. 
Tablo 1: Işletmelerin Faaliyet Türü

\begin{tabular}{lrr}
\hline Üretici-ihracatçı & 132 & $\% 80,0$ \\
İhracatçı & 25 & $\% 15,2$ \\
Grup dış ticaret & 4 & $\% 2,4$ \\
Sektörel dış ticaret & 4 & $\% 2,4$ \\
\hline Toplam & 165 & $\% 100$ \\
\hline
\end{tabular}

Örneklem grubundaki işletmelerin büyüklükleri, çalışan sayılarına göre sınıflandırılmıştır. Buna göre, orta ölçekli olarak nitelenebilecek, 50 ile 249 çalışanı olan işletme sayısı 71; büyük ölçekli olarak varsayılan, 250 ve daha fazla çalışanı bulunan işletme sayısı 53 ve küçük ölçekli olarak nitelenen 49 ve daha az çalışanı mevcut işletme sayısı da 41 olarak gözlemlenmiştir (Tablo 2). İşletme sayılarının ölçek bakımından nispeten dengeli dağılımı anlamlı bir çeşitliliği yansıtmaktadır.

Tablo 2: Işletmelerde Çalışan Sayısı

\begin{tabular}{lrr}
\hline $1-49$ & 41 & $\% 24,9$ \\
$50-249$ & 71 & $\% 43,0$ \\
250 ve üzeri & 53 & $\% 32,1$ \\
\hline Toplam & 165 & $\% 100$ \\
\hline
\end{tabular}

İşletmeler, ihracat miktarlarının toplam satışları içindeki payları bakımından ayrıldığında, 120 işletmenin \%76 ile \%100 arası; 19 işletmenin \%51 ile \%75 arası; 14 işletmenin \%26 ile \%50 arası ve 12 işletmenin \%2 ile \%25 arası ihracat yaptığı görülmüştür (Tablo 3). Bu açıdan, örneklem grubunda ihracat yoğunluğunun yüksek olması dikkat çekmektedir.

Tablo 3: Iş̧letmelerin Satışlarında ihracatın Payı

\begin{tabular}{lrr}
\hline$\% 2-\% 25$ & 12 & $\% 7,3$ \\
$\% 26-\% 50$ & 14 & $\% 8,5$ \\
$\% 51-\% 75$ & 19 & $\% 11,5$ \\
$\% 76-\% 100$ & 120 & $\% 72,7$ \\
\hline Toplam & 165 & $\% 100$ \\
\hline
\end{tabular}

İşletmelere, araştırmaya konu olan müşterilerinin bilgileri de sorulmuştur. Müşteri işletmelerin faaliyet türleri incelendiğinde, 74'ünün toptancl; 71'inin perakendeci; 16'sının üretici; 4'ünün ise hem toptancı hem perakendeci olduğu anlaşılmıştır (Tablo 4). Buna göre, müşteri işletmelerin çoğunluğunun ticaretle uğraştığı, üretici işletmelerin az sayıda bulunduğu görülmüştür. 
Eskişehir Osmangazi Üniversitesi ïBF Dergisi

Tablo 4: Müşteri Işletmenin Faaliyet Türü

\begin{tabular}{lrr}
\hline Toptancı & 74 & $\% 44,9$ \\
Perakendeci & 71 & $\% 43,0$ \\
Üretici & 16 & $\% 9,7$ \\
Toptan ve Perakende & 4 & $\% 2,4$ \\
\hline Toplam & 165 & $\% 100$ \\
\hline
\end{tabular}

İşletmeler ile araştırmaya konu olan müşterileri arasındaki ilişkinin geçmişine bakıldığında, 2 ile 5 yıllık 70; 6 ile 10 yıllık 54; 11 ile 15 yıllık 30; 16 ile 20 yıllık 8; 21 yıllık ve üzeri 3 ilişkiye rastlanmıştır (Tablo 5). Bu noktada, çok uzun süreli ilişkilerin (16 yıl ve üzeri) nadiren bulunması dikkat çekmektedir.

Tablo 5: Iliş̧kinin Yaşı

\begin{tabular}{lcc}
\hline $2-5$ yıl & 70 & $\% 42,5$ \\
$6-10$ yıl & 54 & $\% 32,7$ \\
$11-15$ yıl & 30 & $\% 18,2$ \\
$16-20$ yıl & 8 & $\% 4,8$ \\
21 yıl ve üzeri & 3 & $\% 1,8$ \\
\hline Toplam & 165 & $\% 100$ \\
\hline
\end{tabular}

\section{2. Ölçeklerin Geçerlilik Analizleri}

Güven, memnuniyet ve ilişkisel öğrenme değişkenlerinin toplam 12 ifade ile ölçülen ortalama ve standart sapma değerleri Tablo 6 'da sunulmuştur.

Tablo 6: Ortalama ve Standart Sapmalar

\begin{tabular}{lll}
\hline & Ortalama & Standart sapma \\
\hline Güven & & 0,610 \\
Memnuniyet & 4,086 & 0,542 \\
iliş̧kisel öğrenme & 4,309 & 0,720 \\
\hline
\end{tabular}

Değişkenler arasındaki korelasyonlar (\%95 güven aralığında) Tablo 7'de gösterilmiştir. Tablo 7: Değişkenler Arası Korelasyonlar

\begin{tabular}{lccc}
\hline & $\mathbf{1}$ & $\mathbf{2}$ & $\mathbf{3}$ \\
\hline Güven & 1 & & \\
Memnuniyet &, $760^{* *}$ & 1 & \\
ilişkisel öğrenme &, $392^{* *}$ &, $481^{* *}$ & 1 \\
\hline
\end{tabular}

${ }^{* *} p<0,01$ (çift kuyruklu) 
Araştırmada kullanılan ölçeklerin birleşme ve ayrılma geçerlilikleri, doğrulayıcı faktör analizi yöntemiyle sınanmıştır.

Doğrulayıcı faktör analizi, kovaryans temelli veya bileşen temelli yapısal eşitlik modelleriyle yapılabilmektedir. Bu yöntemler istatistikî açıdan belirgin farklılık göstermektedir (Tenenhaus, 2008). Bileşen temelli yöntem, kısmi en küçük kareler analizini içermekte ve yazında PLS olarak geçmektedir. PLS analizinin, incelenen kavramsal modelde kuramsal altyapının çok güçlü olmadığı ve değişkenler arası ilişkilerin tahmin gücünü anlamaya dönük araştırmalara uygun olduğu belirtilmektedir. Ayrıca, araştırmada toplanan verilerin normal dağılım göstermediği, örtük değişkenlerin az sayıda (1-2) gösterge ile ölçülebildiği, örneklem grubunun küçük (30 civarı) olduğu, modelde çok sayıda (50 ve üzeri) ifadenin yer aldığı, yansıtıcı (reflektif) ve oluşturucu (formatif) ölçeklerin bir arada bulunduğu koşullarda bile PLS analizinin kullanışlı olduğu ifade edilmektedir (Hair vd., 2009). Bu açıklamalara dayanarak, araştırmadaki analizlerin PLS yöntemiyle yapılmasına karar verilmiştir.

Birleşme geçerliliği, göstergelerin (ölçek ifadelerinin) yansıttıkları kabul edilen örtük değişkenlere verdiği yüklerin t değerlerinin, \%95 güven aralığında, anlamlı olmasıyla sağlanmaktadır. Bir yandan da, göstergelerin örtük değişkelerle korelasyon katsayılarının (diğer ifadeyle değişkenlere verdikleri yüklerin), göstergenin ait olduğu örtük değişken için $0,5^{\prime}$ ten az olmaması beklenmektedir (Gefen ve Straub, 2005). Analiz sonucu Tablo 8'de gösterilmiştir.

Tablo 8: Göstergelerin Örtük Değişkenlere Verdiği Yüklerin Anlamlıık Testi

\begin{tabular}{lllll}
\hline Değişkenler (Örtük) & Göstergeler & Yükler & T değeri & P değeri \\
\hline Güven & Güven1 & 0,817 & 21,226 & 0,00 \\
& Güven2 & 0,885 & 49,093 & 0,00 \\
& Güven3 & 0,673 & 7,336 & 0,00 \\
& Güven4 & 0,844 & 23,889 & 0,00 \\
\hline Memnuniyet & Memnun1 & 0,883 & 36,259 & 0,00 \\
& Memnun2 & 0,902 & 34,941 & 0,00 \\
& Memnun3 & 0,935 & 64,440 & 0,00 \\
\hline Illişkisel öğrenme & Öğrenme1 & 0,750 & 13,881 & 0,00 \\
& Öğrenme2 & 0,779 & 17,654 & 0,00 \\
& Öğrenme3 & 0,785 & 17,093 & 0,00 \\
& Öğrenme4 & 0,809 & 20,031 & 0,00 \\
& Öğrenme5 & 0,782 & 18,216 & 0,00 \\
\hline
\end{tabular}

Araştırmada ölçülen kavramlara ilişkin göstergelerin birbirleriyle yüksek, diğerleriyle ise düşük seviyede ilişkili olmasını ifade eden ayrılma geçerliliğinin bir koşulu, örtük değişkenlerin açıkladığı ortalama varyansla (AVE) ilgilidir. Açıklanan ortalama varyans, her bir örtük değişken için, göstergenin örtük değişken tarafından çıkarılan varyans toplamının, örtük değişkenin göstergelerine atfedilen ölçüm hatalarına oranıdır (Gefen ve Straub, 2005). Ayrılma geçerliliği, açıklanan ortalama varyasın, her bir örtük değişken için en az 0,5 olması ve bununla birlikte, bu oranın karekökünün, örtük değişkenin diğerleriyle korelasyon katsayısından yüksek olma- 
sıyla sağlanmaktadır (Fornell ve Larcker, 1981). Değişkenler için açıklanan ortalama varyanslar Tablo 9'da gösterilmiştir. Buna göre tüm oranlar 0,5 düzeyinin üzerindedir.

Tablo 9: Değişkenlerin Açıkladığı Varyans

\begin{tabular}{lc}
\hline Değişkenler & Açılanan ortalama varyans (AVE) \\
\hline Güven & 0,654 \\
Memnuniyet & 0,823 \\
ilişskisel öğrenme & 0,611 \\
\hline
\end{tabular}

Bu koşulun devamı olarak, açıklanan ortalama varyansların karekökü ile değişkenlerin korelasyon katsayıları da Tablo 10'da karşılaştırılmıştır. Her bir örtük değişken için açıklanan ortak varyansların karekökü üst köşegende, kalın puntolu olarak gösterilmiştir. Buna göre, açıklanan ortalama varyansların karekök değeri, ilgili örtük değişkenin diğerleriyle korelasyon katsayısından yüksektir.

Tablo 10: Değişkenlerin Birbirinden Ayrılması

\begin{tabular}{lccc}
\hline & $\mathbf{1}$ & $\mathbf{2}$ & $\mathbf{3}$ \\
\hline Güven & $\mathbf{0 , 8 0 9}$ & & \\
Memnuniyet & 0,760 & $\mathbf{0 , 9 0 7}$ & \\
ilişskisel öğrenme & 0,392 & 0,481 & $\mathbf{0 , 7 8 1}$ \\
\hline
\end{tabular}

Ölçeklerin birleşme ve ayrılma geçerlilik testlerinin ardından, güvenilirlik analizlerine geçilmiştir.

\section{3. Ölçeklerin Güvenilirlik Analizleri}

Ölçeklerin güvenilirliği, farklı zamanlarda ve farklı araştırmacılarca yapılan ölçümlerde aynı sonucu verebilme özelliğini yansıtmaktadır. Bilimsel yazında belirli yaygınlığa ulaşmış çeşitli güvenilirlik analizleri bulunmaktadır. Bu çalışmanın tek bir ölçüm aracı ve tek bir seansta ölçüm içeren araştırma tasarımı göz önüne alındığında, ölçeklerin iç tutarlılık güvenilirliğinin sınanması uygun bulunmuştur (Şencan, 2005).

İç tutarlılık güvenilirliği için sıkça kullanılan yöntemler; madde-toplam puan korelasyonları, Cronbach'ın alfası ve bileşik güvenilirlik değerleridir.

Madde-toplam puan korelasyonu, her bir göstergenin içinde yer aldığı ölçeğin toplam puanıyla korelasyonunu göstermektedir. Bu işlem, madde güvenilirliği olarak da isimlendirilmektedir. Madde-toplam puan korelasyon katsayısının 0,3'ten yüksek olması, ölçekteki göstergelerin iç tutarlılığına işaret eden bulgulardan biridir (Şencan, 2005). Araştırmada kullanılan ölçeklerin madde-toplam puan korelasyonları, Tablo 11 'de sunulmuştur. Buna göre, ilk iç tutarlılık testi olumludur. 
Tablo 11: Ölçeklerin Madde-Toplam Puan Korelasyonları

\begin{tabular}{ll}
\hline Göstergeler & Madde-toplam puan korelasyonları \\
\hline Güven1 &, 550 \\
Güven2 &, 730 \\
Güven3 &, 561 \\
Güven4 &, 755 \\
\hline Memnun1 &, 756 \\
Memnun2 &, 767 \\
Memnun3 &, 844 \\
\hline Öğrenme1 &, 594 \\
Öğrenme2 &, 643 \\
Öğrenme3 &, 655 \\
Öğrenme4 &, 682 \\
Öğrenme5 &, 643 \\
\hline
\end{tabular}

İç tutarlılık analiz yöntemlerinden bir diğeri Cronbach'ın alfa değeridir. Bu değer, bir ölçeğin içerdiği göstergelerin birbirleriyle ne ölçüde tutarlı olduğu ve bağlı bulunduğu örtük değişkeni ne ölçüde temsil ettiği hakkında bilgi vermektedir (Şencan, 2005). Genel kabul olarak, Cronbach'ın alfa değerinin 0,7 seviyesinin üzerinde olması beklenmektedir (Lowry ve Gaskin, 2014). Araştırmanın ölçeklerine ilişkin alfa değerleri Tablo 12 'de gösterilmiştir. Bu verilere göre, ikinci iç tutarlılık testinin sonucu da olumlu bulunmuştur.

Tablo 12: Değişkenlerin Cronbach'ın Alfa Değerleri

\begin{tabular}{lc}
\hline Değişkenler & Alfa \\
\hline Güven & 0,825 \\
Memnuniyet & 0,892 \\
ilişkisel öğrenme & 0,840 \\
\hline
\end{tabular}

İç tutarlılık güvenilirliği testlerinden bir başkası bileşik güvenilirlik katsayısıdır. Bileşik güvenilirlik, örtük değişkene atfedilebilecek ölçüm varyansının oranı, bir diğer ifadeyle, değişken varyansının, değişken ve hata varyansının toplamına oranıdır (Şencan, 2005). İç tutarlılık için, bu değerin de 0,7'nin üzerinde olması tavsiye edilmektedir (Lowry ve Gaskin, 2014). Ölçeklerin bileşik güvenilirlik katsayıları Tablo 13'de sunulmuştur. Bu değerler de araştırmada kullanılan ölçeklerin iç tutarlılık güvenilirliğine işaret etmektedir.

Tablo 13: Değişkenlerin Bileşik Güvenilirlikleri

\begin{tabular}{lc}
\hline Değişkenler & Bileşik güvenilirlik \\
\hline Güven & 0,882 \\
Memnuniyet & 0,933 \\
Illişkisel öğrenme & 0,887 \\
\hline
\end{tabular}


Araştırma bulgularını etkileyebilecek diğer bir durum cevaplanmama yanlılığıdır. Cevaplanmama yanlıı̆̆ı, örneklem grubu içerisinde, araştırmaya katılanlar ile katılmayanlar arasındaki muhtemel varyanstan kaynaklanmaktadır (Bankowska vd., 2015). Bu araştırmadaki etkin dönüş oranının \%27,6 olduğu dikkate alındığında, cevap vermeme yanlılığına ilişkin bir test yapılması gerekmiştir. Öte yandan, veriler anonim biçimde toplandığından, örneklem grubundaki işletmelerin hangilerinin araştırmaya katılıp hangilerinin katılmadığına dair bir veri bulunmamaktadır. Buna alternatif yapılabilecek bir analiz olarak, araştırmaya birinci çağrıda katılanlar ile hatırlatma çağrısından sonra katılanların demografik özelliklerinin karşılaştırılması önerilmektedir (Leonidou vd., 2011). Buna göre, analiz edilen 165 gözlem içinden, araştırmaya erken cevap veren 110 işletme ile geç cevap veren 55 işletme, büyüklük, yaş, ihracat geçmişi, ihracat yapılan ülke sayısı ve ihracat hacminin toplam satışlardaki payı ölçütlerine göre karşılaştırılmıştır. Bağımsız grup t testleri sonucu Tablo 14'te gösterilmiştir. Iki grup işletme arasında, bu özelliklere göre anlamlı bir fark bulunmadığından, toplanan veriler açısından cevaplanmama yanlıığı ihtimalinin düşük olduğu çıkarımı yapılmıştır.

Tablo 14: Erken ve Geç Cevap Verenlerin Karşılaştırılması

\begin{tabular}{lccc}
\hline İşletme Özellikleri & Ortalamalar farkı & T değeri & P değeri \\
\hline İşletmenin büyüklüğü & 12,145 &, 102 & 0,919 \\
İşletmenin yaşı & $-0,291$ &,- 150 & 0,881 \\
ìnracat geçmişi & $-0,709$ &,- 445 & 0,658 \\
ìnracat yapılan ülke sayısı & 2,791 & 1,085 & 0,280 \\
ìhracatın satışlardaki payı & 3,645 &, 783 & 0,436 \\
\hline
\end{tabular}

Ölçeklerin geçerlilik ve güvenilirlik testlerinin ardından, değişkenlerin bir üst kavram oluşturmasına ilişkin analize geçilmiştir.

\section{4. İlişki Kalitesinin Sınanması}

Önceki bölümlerde, ilişki kalitesinin, güven, memnuniyet ve ilişkisel öğrenme boyutlarından oluşan bir üst kavram şeklinde ele alındığı açıklanmıştı. Bu üst kavramın görgül biçimde hesaplanmasında, özel bir yöntem izlenmesi gerekmiştir. Bu yöntemi aktarmadan önce, araştırmalarda kullanılan ölçeklerin türlerine yönelik genel bir ayrımdan bahsetmek gerekmektedir. Bu ayrım ölçeklerin yansıtıcı (reflektif) veya oluşturucu (formatif) niteliğine dayalıdır. Yansıtıcı ölçekler, göstergelerin örtük değişkenden etkilendiği, onu yansıttığı yaklaşımından yola çıkmaktadır. Keza, bu araştırmadaki üç örtük değişkenin, 12 gösterge tarafından yansıtıldığı kabul edilmiştir. Oluşturucu ölçekler ise, göstergelerin değişkeni etkilediği, onu oluşturduğu varsayımıyla hareket etmektedir. Bu durumda, göstergelerin bir bütünün farklı parçaları olduğu, dolayısıyla aralarında bir korelasyon aranmadığı gibi, bir göstergenin diğerinin yerine geçemeyeceği de vurgulanmaktadır (Coltman vd., 2008). Araştırma ölçekleri belirlenirken, yansıtıcı veya oluşturucu türün benimsenmesi, örtük değişkene kavramsal bakış açısını tamamen değiştirmek anlamına gelmektedir. Öte yandan, oluşturucu ölçeklerin geçerliliğinin nasıl sınanacağı hakkında, yazında genel kabul görmüş bir yol bulunmamaktadır (Diamantopoulos ve Winklhofer, 2001; Freeze ve Raschke, 2007).

Lee ve Cadogan (2013) alt boyutlarının (birinci düzey) yansıtıcı ölçeklerle hesaplandığı bir üst kavramın (ikinci düzey), bu alt boyutlar tarafından oluşturulacağının kabul edilmesi gerektiğini vurgulamaktadır. Diğer türlü yaklaşımın, başka bir ifadeyle iki düzeyde de yansıtıcı ölçe- 
ğin, yanıltıcı veya anlamsız olacağının altını çizmektedir. Bu açıdan bakıldığında, birinci düzey değişkenlerin oluşturduğu ikinci düzey değişkenin ölçek geçerliliği için yalın bir kural, alt boyutların üst kavramla kısmi korelasyon katsayılarının, anlamlı ve birbirine yakın olmasıdır (Lowry ve Gaskin, 2014).

Araştırma modelinde, güven, memnuniyet ve ilişkisel öğrenme ile oluştuğu kabul edilen ilişki kalitesi için yukarıda bahsedilen PLS analizi uygulanmıştır. Buna göre, bu üç alt boyutun üst kavramı olarak varsayılan ilişki kalitesi üzerindeki ağırlıkları \%95 güven aralığında anlamlı ve tümü 0,4 seviyesindedir (Tablo 15).

Tablo 15: ikinci Düzey Değişkendeki Ağırlıklar

\begin{tabular}{lccc}
\hline & $\begin{array}{c}\text { Standardize katsayı- } \\
\text { lar }\end{array}$ & T değeri & P değeri \\
\hline Güven $\rightarrow$ İlişki kalitesi & 0,402 & 15,313 & 0,000 \\
Memnuniyet $\rightarrow$ İlişki kalitesi & 0,391 & 17,679 & 0,000 \\
İlişkisel öğrenme $\rightarrow$ İlişki kalitesi & 0,406 & 12,405 & 0,000 \\
\hline
\end{tabular}

$\mathrm{Bu}$ analize ek olarak, ilişki kalitesinin boyutları biçiminde öne sürülen güven, memnuniyet ve ilişkisel öğrenme değişkenlerinin çapraz yükleri hesaplanmıştır. Buna göre, örtük değişkenlere ait gösterge yüklerinin, diğer değişkenlerinkinden yüksek olduğu görülmüştür (Tablo 16).

Tablo 16: ilişki Kalitesi Boyutlarının Çapraz Yükleri

\begin{tabular}{llll}
\hline & Güven & Memnuniyet & ilişkisel öğrenme \\
\hline Güven1 & 0,817 & 0,653 & 0,304 \\
Güven2 & 0,885 & 0,632 & 0,346 \\
Güven3 & 0,673 & 0,489 & 0,275 \\
Güven4 & 0,844 & 0,672 & 0,320 \\
Memnun1 & 0,734 & 0,883 & 0,387 \\
Memnun2 & 0,653 & 0,902 & 0,471 \\
Memnun3 & 0,693 & 0,935 & 0,440 \\
Öğrenme1 & 0,341 & 0,437 & 0,750 \\
Öğrenme2 & 0,313 & 0,384 & 0,779 \\
Öğrenme3 & 0,381 & 0,385 & 0,785 \\
Öğrenme4 & 0,188 & 0,352 & 0,809 \\
Öğrenme5 & 0,293 & 0,316 & 0,782 \\
\hline
\end{tabular}

Tüm bu bulgulara dayanarak, üç boyutlu ilişki kalitesi ölçeğinin ve daha önemlisi bu çalışmadaki kavramsallaştırmanın geçerli olduğu çıkarımı yapılmıştır.

\section{Tartışma}

Mevcut işletmeler arası ilişki kalitesi yazını incelendiğinde, konuya çeşitli açılardan yaklaşan araştırmalar olduğu görülmektedir. Eserlerde ilişki kalitesine dair farklı tanımlar ile pek çok değişik alt boyutlar bulunmakta ve kavram hakkında bir mutabakattan bahsedilememektedir. Kavramı uluslararası ticaret perspektifinden inceleyen araştırmaların sayısında da, özellikle 
son on yıldır artış gözlenmektedir. Öte yandan, ilişki kalitesini uluslararası ticaretin yarattığı özel koşullar çerçevesinde kavramsallaştıran eserler çok sınırlıdır (Leonidou vd., 2014). Bu çalışmada, bahsedilen boşluktan hareketle bir araştırma tasarlanmıştır. İlişki kalitesi; ilişkide yaşanan sürtüşmenin az, ilişkiden sağlanan faydanın çok olduğuna dair algının derecesi biçiminde tanımlanmış; kavramın alt boyutlarının güven, memnuniyet ve ilişkisel öğrenme olduğu öngörülmüştür. Bu kavramsallaştırma, Woo ve Ennew'in (2004) işletmeler arası ilişki kalitesinin genel bir perspektif olarak düşünülmesi ve araştırılan bağlama özgün alt boyutlarının tespit edilmesine dair önerisiyle de örtüşmektedir. Diğer yandan, güven ve memnuniyet, ilişki kalitesinin tanımlanmasında en sık kullanılan boyutlar olsa da, ilişkisel öğrenme kavramı nadiren ele alınmaktadır. Hâlbuki başka çevrelerden gelen işletmeler arasındaki farklılıkların, bir öğrenme kaynağı olduğu varsayımının (Nooteboom, 2008) dikkate alınması, bu kapsamdaki çalışmalar için daha makul gözükmektedir. Nitekim bu araştırmanın bulguları, bahsedilen yaklaşımı desteklemektedir.

Uluslararası ticarette ilişki kalitesini inceleyen görgül çalışmalarda olgu -buradaki gibi- farkIı alt boyutlardan oluşan bir üst kavram olarak ele alınmaktadır. Örneğin; Nguyen ve Nguyen (2010), Ahamed ve Skallerud (2013), Hoppner vd. (2015), Velez vd. (2015) de bunu nicel olarak sınamış ve geçerli bulmuştur. Öte yandan, bu eserlerde ilgili alt boyutlar belirlenirken önceki çalışmalara referans verilmekte fakat uluslararası ticarete özgü bir kavramsallaştırma öne sürülmemektedir. Hatta Lages vd.'nin (2005) ihracat pazarları için geliştirdiği ilişki kalitesi ölçeğinde bile; bilgi paylaşımı, iletişim kalitesi, uzun dönemli işbirliği yönelimi ve memnuniyet gibi tüm ilişkiler için geçerli olabilecek boyutlar kullanılmıştır. Buna karşın, Skarmeas ve meslektaşları (2008) ile Skarmeas ve Robson (2008) ele aldıkları ilişki kalitesinin güven, bağlılık, memnuniyet ve çatışmasızlık alt boyutlarını, dış ticaret yöneticileriyle yaptıkları görüşmelere dayanarak tespit ettiklerini belirtmişlerdir. Gerçi bu kavramlar da yazındaki ilişki kalitesi tanımları için en sık başvurulan boyutlar arasındadır. Bunların dışında, Raskovic vd. (2013) nispeten dar kapsamlı araştırmalarında, çok uluslu alım-satım ilişkilerinde, ilişkisel öğrenmenin rolünü vurgulamıştır. Buradan hareketle, bu çalışmada uluslararası ticarette ilişki kalitesi yeniden kavramsallaştırılmış ve buna özgü boyutlar ortaya konmuştur. Elde edilen bilginin, akademik yazına katkı sağlayacağı düşünülmektedir.

\section{Sonuç}

Dünya genelinde uluslararası ticaretin hızla gelişmekte olması, işletmeler arası ilişkilerde yeni bir katman yaratmaktadır. Iliş̧iler uluslararası nitelik kazandığında, işbirliği süreci daha karmaşık hale gelmektedir çünkü mevcut değişken duruma, taraflar ve içinde bulundukları ortamlar arasındaki farklııklar da eklemektedir. İşletmeler arası mesafe, işletmeleri çevreleyen coğrafi, siyasi, ekonomik, teknolojik ve kültürel koşullar altında çeşitli dinamikler yaratmakta ve ilişkideki taraflar arasında özel bir iklim oluşturmaktadır. Bu iklim, işletmelerin rekabet güçlerini dahi etkileyebilmektedir. Dolayısıyla, ilişkilerin derinliğini ve gücünü değerlendirmek hem teorik hem pratik açıdan önem kazanmaktadır. Bunun yöntemlerinden biri işletmeler arası ilişki kalitesine odaklanmaktır.

Bu çalışmada uluslararası ticarette ilişki kalitesinin özgün bir tanımı yapılmış ve alt boyutlarının güven, memnuniyet ve ilişkisel öğrenme olduğu öne sürülmüştür. Ardından yapılan görgül incelemede, bunu destekleyen bulgular ortaya konmuştur. İlişkisel öğrenmenin uluslararası ticarette ilişki kalitesinin boyutlarından biri olarak yer bulması bilhassa vurgulanmalıdır. Bu yüzden çalışmanın, ilişkisel öğrenme olgusunun, uluslararası ticarette işletmeler arası ilişki kalitesindeki rolünü tespit etmesi açısından, özgün değer taşıdığı düşünülmektedir. 
Elbette, bu araştırmanın bulguları, kendi kapsamında geçerli olmakta ve bazı kısıtlar içermektedir. Öncelikle, araştırma için nicel yöntem benimsenmiştir. Araştırmanın temel öngörüsü daha çok mantığa ve alanda yapılmış önceki çalışmaların tespitlerine dayanmaktadır. Dolayısıyla, nitel yöntemlerle elde edilecek bilgilerin katkısı bu araştırmaya yeterince yansımamıştır. Ayrıca, veriler kesitsel, diğer bir ifadeyle tek bir seansta toplanmıştır. Bu yüzden, zamana dayalı olarak ilişkilerdeki değişimleri saptamak mümkün olmamıştır. Bunlarla beraber, yazın incelemesinde de çok rastlandığı üzere, birden fazla aktörü içeren ilişki kavramı hakkında sadece tek taraflı veri toplanabilmiştir. Ilişkiler sadece satıc işletmeler açısından değerlendirilmiştir. Araştırmanın bir başka kısıtı, her ne kadar örneklem grubu sistematik şekilde belirlenmiş ve böylece pek çok değişkeni kontrol etme gereği azalmış olsa da, veri tek bir sektör ve tek bir coğrafi bölgeden toplanmıştır. Bu bahsedilen kısıtlar, araştırma bulgularının genellenebilme gücünü düşürmektedir. Öte yandan, araştırma tasarımının sistematik ve istatistikî analizlerin tutarlı olması, araştırmayı kapsamı dâhilinde güçlü kılmaktadır.

Sonuçta, bu araştırma ile uluslararası endüstriyel alım-satım ilişkilerinde, ilişkisel öğrenmenin ilişkideki rolünün altı çizilmiştir. Benzer çerçevedeki gelecek araştırmalarda, ilişki kalitesinin öncelleri ve sonuçları irdelenirken bu boyutun da dikkate alınması önerilmektedir. 


\section{Eskişehir Osmangazi Üniversitesi IïB Dergisi}

\section{Kaynaklar}

Adler, Paul S. (2001), "Market, Hierarch, and Trust: The Knowledge Economy and the Future of Capitalism”, Organization Science, Vol. 12, No. 2: 215-234.

Ahamed, A.F.M Jalal; Skallerud, Karo (2013), "Effect of Distance and Communication Climate on Export Performance: The Mediating Role of Relationship Quality", Journal of Global Marketing, Vol. 26, No. 5: 284-300.

Ahmed, Farid; Patterson, Paul; Styles, Chris (1999), "The Determinants of Successful Relationships in International Business", Australasian Marketing Journal, Vol. 7, No: 1: 5-21.

Anderson, James C.; Narus, James A. (1984), “A Model of The Distributor's Perspective of Distributor-Manufacturer Working Relationships", Journal of Marketing, No. 48: 62-74.

Anderson, James C.; Narus, James A. (1991), "Partnering as a Focused Market Strategy", California Management Review, Vol. 33, No. 3: 95-113.

Anderson, Erin; Weitz, Barton (1989), "Determinants of Continuity in Conventional Industrial Channel Dyads", Marketing Science, Vol. 8, No. 4: 310-323.

Anderson, James C.; Hakansson, Hakan; Johanson, Jan (1994), "Dyadic Business Relationships Within a Business Network Context", Journal of Marketing, Vol. 58, No. 4: 1-15.

Ambos, Tina C.; Ambos, Björn (2009), "The Impact of Distance on Knowledge Transfer Effectiveness in Multinational Corporations", Journal of International Management, No. 15: 1-14.

Arino, Africa; De la Torre, Jose; Ring, Peter Smith (2001), "Relational Quality: Managing Trust in Corporate Alliances", California Management Review, Vol. 44, No. 1: 109-131.

Arrow, Kenneth (1974). The Limits of Organization. New York: Norton.

Aulakh, Preet S.; Kotabe, Masaaki; Sahay, Arvind (1996), "Trust and Performance in Cross-Border Marketing Partnerships: A Behavioral Approach”, Journal of International Business Studies, Vol. 27, No. 5: 1005-1032.

Azdegan, Arash; Dooley, Kevin J.; Carter, Phillip L.; Carter, Joseph R. (2008), "Supplier Innovativeness and the Role of Interorganizational Learning in Enhancing Manufacturer Capabilities", Journal of Supply Chain Management, Vol. 44, No. 4: 14-35.

Bachman, Reinhard; Zaheer, Akbar (2008), "Trust in inter-organizational relations", (Ed. Steve Cropper, Chris Huxham, Mark Ebers, Peter Smith Ring), The Oxford Handbook of Inter-Organizational Relations, Oxford: Oxford University Press: 533-554.

Baier, Annette (1985), Postures of the Mind: Essays on Mind and Morals. Minneapolis: University of Minnesota Press.

Bankowska, Katarzyna; Osiewicz, Malgorzata; Perez-Duarte, Sebastien (2015), "Measuring Non-Response Bias in a Cross-Country Enterprise Survey", European Central Bank Statistics Paper Series, No. 12: 1-28.

Barry, James M.; Doney, Patricia M. (2011), "Cross-Cultural Examination of Relationship Quality", Journal of Global Marketing, No. 24: 305-323.

Bradach, Jeffrey L.; Eccles, Robert G. (1989), "Price, Authority, and Trust: From Ideal Types to Plural Forms", Annual Review of Sociology, No. 15: 97-118.

Bruggen, Gerrit H.V.; Kacker, Manish; Nieuwlaat, Chantal (2005), "The Impact of Channel Function Performance on Buyer-Seller Relationships in Marketing Channels", International Journal of Research in Marketing, No. 22: 141158.

Burkert, Michael; Ivens, Björn Sven; Shan, Jialu (2012), “Governance Mechanisms in Domestic and International Buyer-Supplier Relationships: An Empirical Study", Industrial Marketing Management, No. 41: 544-556.

Cambra-Fierro, Jesus J.; Polo-Redondo, Yolanda (2008), "Creating Satisfaction in the Demand-Supply Chain: The Buyers' Perspective", Supply Chain Management: An International Journal, Vol. 13, No. 3: 211-224.

Capon, Noel; Glazer, Rashi (1987), “Marketing and Technology: A Strategic Coalignment”, Journal of Marketing, Vol. 51, No. 3: 1-14.

Cater, Tomaz; Cater, Barbara (2010), "Relationship-value-Based Antecedents of Customer Satisfaction and Loyalty in Manufacturing", Journal of Business \& Industrial Marketing, Vol. 24, No. 8: 585-597.

Chang, Man-Ling; Cheng, Cheng-Feng; Wu, Wann-Yih (2012), "How Buyer-Seller Relationship Quality Influences Adaptation and Innovation by Foreign MNCs' Subsidiaries", Industrial Marketing Management, No. 41: 10471057. 
Chinomona, Richard (2013), “Dealer's Legitimate Power and Relationship Quality in Gaunxi Distribution Channel: A Social Rule System Theory Perspective", International Journal of Marketing Studies, Vol. 5, No. 1: 42-58.

Collis, David J. (1991), "A Resource-Based Analysis of Global Competition: The Case of Bearing Industry", Strategic Management Journal, No. 12: 49-68.

Coltman, Tim; Devinney, Timothy M.; Midgley, David F.; Venaik, Sunil (2008), "Formative versus Reflective Measurement Models: Two Applications of Formative Measurement", Journal of Business Research, No. 61: 1250-1262.

Crosby, Lawrence A.; Evans, Kenneth R.; Cowles, Deborah (1990), "Relationship Quality in Services Selling: An Interpersonal Influence Perspective", Journal of Marketing, No. 54: 68-81.

Diamantopoulos, Adamantios; Winklhofer, Heidi M. (2001), "Index Construction with Formative Indicators: An Alternative to Scale Development", Journal of Marketing Research, Vol. 38, No. 2: 269-277.

Dorsch, Michael J.; Swanson, Scott R.; Kelley, Scott W. (1998), "The Role of Relationship Quality in The Stratification of Vendors as Perceived by Customers", Journal of the Academy of Marketing Science, Vol. 26, No. 2: 128-142.

Dwyer, F. Robert; Oh, Sejo (1987), "Output Sector Munificence Effects on the Internal Political Economy of Marketing Channels", Journal of Marketing Research, No. 24: 347-358.

Dwyer, F.Robert; Schur, Paul H.; Oh, Sejo (1987), “Developing buyer-Seller Relationships", Journal of Marketing, No. 51: 11-27.

Dyer, Jeffrey H.; Singh, Harbir (1998), "The Relational View: Cooperative Strategy and Sources of Interorganizational Competitive Advantage", Academy of Management Review, Vol. 23, No. 4: 660-679.

Fornell, Claes; Larcker, David F. (1981), "Evaluating Structural Equation Models with Unobservable Variables and Measurement Error", Journal of Marketing Research, Vol. 18, No. 1: 39-50.

Freeze, Ronald D.; Raschke, Robyn L. (2007), "An Assessment of Formative and Reflective Constructs in IS Research", ECIS 2007 Proceedings: 1481-1492.

Fukuyama, Francis (1995), Trust: The Social Virtues and the Creation of Prosperity. New York: The Free Press.

Fynes, Brian; Burca, Sean; Marshall, Donna (2004), "Environmental Uncertainty, Supply Chain Relationship Quality and Performance", Journal of Purchasing \& Supply Management, No. 10: 179-190.

Ganesan, Shankar (1994), "Determinants of Long-Term Orientation in Buyer-Seller Relationships”, Journal of Marketing, Vol. 58, No. 2: 1-19.

Gefen, David; Straub, Detmar (2005), “A Practical Guide to Factorial Validity Using PLLS-Graph: Tutorial and Annotated Example", Communications of the Association for Information Systems, No. 16: 91-109.

Geyskens, Inge; Steenkamp, Jan-Benedict E.M.; Kumar, Nirmalya (1999), “A Meta-Analysis of Satisfaction in Marketing Channel Relationships", Journal of Marketing Research, Vol. 36, Iss. May: 223-238.

Geyskens, Inge; Steenkamp, Jan-Benedict E.M. (2000), "Economic and Social Satisfaction: Measurement and Relevance to Marketing Channel Relationships", Journal of Retailing, Vol. 76, No. 1: 11-32.

Gulati, Ranjay; Singh, Harbir (1998), "The Architecture of Cooperation: Managing Coordination Costs and Appropriation Concerns in Strategic Alliances", Administrative Science Quarterly, No. 43: 781-814.

Gulati, Ranjar; Sytch, Maxim (2008), "Does Familiarity Breed Trust? Revisiting the Antecedents of Trust", Managerial and Decision Economics, No. 29: 165-190.

Hair, Joseph F.; Black, William C.; Babin, Barry J.; Anderson, Rolph E. (2009), Multivariate Data Analysis. Essex: Pearson.

Hakansson, Hakan (1982), International Marketing and Purchasing of Industrial Goods: An Interaction Approach. New York: Wiley.

Hakansson, Hakan; Havila, Virpi; Pedersen, Ann-Charlott (1999), "Learning in Networks", Industrial Marketing Management, No. 18: 443-452.

Hennig-Thurau, Thorsten; Gwinner, Kevin P.; Gremler, Dwayne D. (2002), “Understanding Relationship Marketing Outcomes: An Integration of Relational Benefits and Relationship Quality", Journal of Service Research, Vol. 4, No. 3: 230-247.

Holmlund, Maria (2008), "A Definition, Model, and Empirical Analysis of Business-to-Business Relationship Quality", International Journal of Service Industry Management, Vol. 19, No. 1: 32-62. 


\section{Eskişehir Osmangazi Üniversitesi IïB Dergisi}

Hoppner, Jessica J.; Griffith, David A.; White, Ryan C. (2015), "Reciprocity in Relationship Marketing: A Cross-Cultural Examination of the Effects of Equivalence and Immediacy on Relationship Quality and Satisfaction with Performance", Journal of International Marketing, Vol. 23, No. 4: 64-83.

Humphrey, John; Schmitz, Hubert (1998), "Trust and Inter-Firm Relations in Developing and Transition Economies", The Journal of Development Studies, Vol. 34, No. 4: 32-61.

Huntley, Julie K. (2006), “Conceptualization and Measurement of Relationship Quality: Linking Relationship Quality to Actual Sales and Recommendation Intention", Industrial Marketing Management, No. 35: 703-714.

Hutchinson, David; Wellington, William J.; Saad, Mohammed; Cox, Phillip (2011), "Refining Value-Based Differentiation in Business Relationships: A Study of the Higher Order Relationship Building Blocks That Influence Behavioural Intentions", Industrial Marketing Management, No. 40: 465-478.

Ivens, Björn Sven; Pardo, Catherine (2007), “Are Key account Relationships Different? Empirical Results on Supplier Strategies and Customer Reactions", Industrial Marketing Management, No. 36: 470-482.

Jap, Sandy D.; Manolis, Chris; Weitz, Barton A. (1999), "Relationship Quality and Buyer-Seller Interactions in Channels of Distribution", Journal of Business Research, No. 46: 303-313.

Jean, Ruey-Jer; Sinkovics, Rudolf R.; Kim, Daekwan (2010), “Drivers and Performance Outcomes of Relationship Learning for Suppliers in Cross-Border Customer-Supplier Relationships: The Role of Communication Culture", Journal of International Marketing, Vol. 18, No. 1: 63-85.

Johnson, Jean L. (1999), "Strategic Integration in Industrial Distribution Channels: Managing the Interfirm Relationship as Strategic Asset", Journal of the Academy of Marketing Science, Vol. 27, No. 1: 4-18.

Johnston, Wesley J.; Khalil, Shadab; Jain, Megha; Cheng, Julian Ming-Sung (2012), "Determinants of Joint Action in International Channels of Distribution: The Moderating Role of Psychic Distance", Journal of International Marketing, Vol. 20, No. 3: 34-49.

Kang, Bohyeon; Oh, Sejo; Sivadas, Eugene (2013), "Beyond Relationship Quality: Examining Relationship Management Effectiveness", Journal of Marketing Theory and Practice, Vol. 21, No. 3: 273-287.

Kohtamaki, Marko; Bourlakis, Michael (2012), “Antecedents of Relationship Learning in Supplier Partnerships from the Perspective of an Industrial Customers: The Direct Effects Model", Journal of Business \& Industrial Marketing, Vol. 27, No. 4: 299-310.

Lages, Carmen; Lages, Cristiana Raquel; Lages, Luis Felipe (2005), "The RELQUAL Scale: A Measure of Relationship Quality in Export Market Ventures", Journal of Business Research, No. 58: 1040-1048.

Lahiri, Somnath; Kedia, Ben L. (2011), “Determining Quality of Business-to-Business Relationships: A Study of Indian ITT-Enabled Service Providers", European Management Journal, No. 29: 11- 24.

Lane, Christel; Bachmann, Reinhard (1996), "The Social Constitution of Trust: Supplier Relations in Britain and Germany", Organization Studies, Vol. 17, No. 3: 365-395.

Lee, Nick; Cadogan, John W. (2013), "Problems with Formative and Higher-Order Reflective Variables", Journal of Business Research, No. 66: 242-247.

Leonidou, Leonidas C.; Palihawadana, Dayananda; Chari, Simos; Leonidou, Constantinos N. (2011), "Drivers and Outcomes of Importer Adaptation In International Buyer-Seller Relationships", Journal of World Business, No. 46: 527-543.

Leonidou, Constantinos N.; Leonidou, Leonidas C.; Coudounaris, Dafnis N.; Hultman, Magnus (2013), "Value Differences as Determinants of Importers' Perceptions of Exporters' Unethical Behavior: The Impact on Relationship Quality and Performance", International Business Review, No. 22: 156-173.

Leonidou, Leonidas C.; Barnes, Bradlet R.; Talias, Michael A. (2006), “Exporter-Importer Relationship Quality: The Inhibiting Role of Uncertainty, Distance, snd Conflict”, Industrial Marketing Management, Vol. 35, No. 5: 576588.

Leonidou, Leonidas C.; Samiee, Saeed; Aykol, Bilge; Talias, Michael A. (2014), “Antecedents and Outcomes of Exporter-Importer Relationship Quality: Synthesis, Meta-Analysis, and Directions for Further Research", Journal of International Marketing, Vol. 22, No. 2: 21-46.

Levinson, Nanette S.; Asahi, Minoru (1995), “Cross-National Alliances and Interorganizational Learning”, Organizational Dynamics, Vol. 24, No. 2: 50-63.

Levitt, Barbara; March, James G. (1988), “Organizational Learning”, Annual Review of Sociology, No. 14: 319-340. 
Lowry, Paul Benjamin; Gaskin, James (2014), "Partial Least Squares (PLS) Structural Equation Modeling (SEM) for Building and Testing Behavioral Causal Theory: When to Choose It and How To Use It", IEEE Transactions on Professional Communication, Vol. 57, No. 2: 123-146.

Macaulay, Stewart (1963), "Non-Contractual Relations in Business: A Preliminary Study", American Sociological Review, No. 28: 55-67.

Madhok, Anoop (1995), "Revisiting Multinational Firms' Tolerance for Joint Ventures: A Trust-Based Approach", Journal of International Business Studies, Vol. 26, No. 1: 117-137.

Marquardt, Adam J. (2013), "Relationship Quality as a Resource to Build Industrial Brand Equity When Products are Uncertain and Future-Based", Industrial Marketing Management, No. 42: 1386-1397.

Moorman, Christine; Zaltman, Gerald; Deshpande, Rohit (1992), "Relationships between Providers and Users of Market Research: The Dynamics of Trust within and Between Organizations", Journal of Marketing Research, Vol. 29, Iss. August: 314-328.

Mysen, Tore; Svensson, Goran; Högevold, Nils (2012), "Relationship Quality-Relationship Value and Power Balance in Business Relationships: Descriptives and Propositions", Journal of Business-to-Business Marketing, No. 19: 248285.

Nevins, Jennifer L.; Money, R. Bruce (2008), “Performance Implications of Distributor Effectiveness, Trust, and Culture in Import Channels of Distribution", Industrial Marketing Management, No. 37: 46-58.

Nguyen, Trang T.M.; Nguyen, Tho D. (2010), "Learning to Build Quality Business Relationships in Export Markets: Evidence from Vietnamese Exporters", Asia Pacific Business Review, Vol. 16, No. 1-2: 203-220.

Nonaka, Ikujiro (1994), “A Dynamic Theory of Organizational Knowledge Creation”, Organization Science, Vol. 5, No. 1: 14-37.

Nooteboom, Bart (2008), "Learning and Innovation in Inter-Organizational Relationships", (Ed. Steve Cropper, Chris Huxham, Mark Ebers, Peter Smith Ring), The Oxford Handbook of Inter-Organizational Relations, Oxford: Oxford University Press: 608-634.

Nyaga, Gilbert N.; Whipple, Judith M. (2011), “Relationship Quality and Performance Outcomes: Achieving a Sustainable Competitive Advantage", Journal of Business Logistics, Vol. 32, No. 4: 345-360.

Oba, Beyza; Semerciöz, Fatih (2005), "Antecedents of Trust in Industrial Districts: An Empirical Analysis of Inter-Firm Relations in a Turkish Industrial District", Entrepreneurship \& Regional Development, No. 17: 163-182.

Oliver, Richard L. (1980), "A Cognitive Model of the Antecedents and Consequences of Satisfaction Decision”, Journal of Marketing Research, Vol. 17, Iss. November: 460-469.

Oliver, Christine (1990), "Determinants of Interorganizational Relationships: Integration and Future Directions", Academy of Management Journal, Vol. 15, No. 2: 241-265.

Palmatier, Robert W. (2008), “Interfirm Relational Drivers of Customer Value”, Journal of Marketing, No. 72: 76-89.

Provan, Keith G.; Sydow, Joerg (2008), "Evaluating Inter-Organizational Relationships", (Ed. Steve Cropper, Chris Huxham, Mark Ebers, Peter Smith Ring), The Oxford Handbook of Inter-Organizational Relations, Oxford: Oxford University Press: 691-716.

Raskovic, Matevz; Ferligoj, Anuska; Brencic, Maja Makovec; Fransoo, Jan C. (2013), "Relationship Learning as a Dimension of Relationship Quality: Tentative Evidence from Transnational Buyer-Supplier Relationships", Trziste, No. 25: 37-50.

Ring, Peter Smith; van de Ven, Andrew H. (1992), "Structuring Cooperative Relationships between Organizations", Strategic Management Journal, No. 13: 483-498.

Ritter, Thomas; Gemünden, Hans Georg (2003), "Interorganizational relationships and networks: An overview", Journal of Business Research, Vol. 56, No. 9: 691-697.

Schurr, Paul H.; Ozanne, Julie L. (1985), “Influences on Exchange Processes: Buyers' Preconceptions of a Seller's Trustworthiness and Bargaining Toughness", Journal of Consumer Research, Vol. 11, No. 4: 939-953.

Selnes, Fred; Sallis, James (2003), "Antecedents and Consequences of Trust and Satisfaction in Buyer-Seller Relationships", European Journal of Marketing, Vol. 32, No. 3-4: 305-322.

Semerciöz, Fatih (2000), işsletmeler Arası Ilişkilerde Şebeke Organizasyon Yapıları ve Endüstriyel Bölgelerdeki Şebeke Organizasyon Yapısında Ortaya Çıkan Güven İlişkisi Üzerine Bir Araştırma (Doktora tezi). İstanbul Üniversitesi Sosyal Bilimler Enstitüsü. 


\section{Eskişehir Osmangazi Üniversitesi IïB Dergisi}

Skarmeas, Dionysis; Robson, Mathew J. (2008), “Determinants of Relationship Quality in Importer-Exporter Relationships", British Journal of Management, No. 19: 171-184.

Skarmeas, Dionysis; Katsikeas, Constantine S.; Spyropoulou, Stavroula; Salehi-Sangari, Esmail (2008), "Market and Supplier Characteristics Driving Distributor Relationship Quality in International Marketing Channels of Industrial Products", Industrial Marketing Management, No. 37: 23-36.

Smith, Brock (1998), "Buyer-Seller Relationships: Bonds, Relationship Management, and Sex Type", Canadian Journal of Administrative Sciences, Vol. 15, No. 1: 76-92.

Sözüer, Aytuğ (2016), Uluslararası Ticarette Işletmeler Arasi Iliş̧i Kalitesi: Türkiye'deki ihracatçi Firmalarin Yurt Dışındaki Müşterileriyle Illişkileri Üzerine Bir Araştırma (Doktora tezi). İstanbul Üniversitesi Sosyal Bilimler Enstitüsü.

Şencan, Hüner (2005), Sosyal ve Davranışsal Ölçümlerde Güvenilirlik ve Geçerlilik, Ankara: Seçkin.

Tenenhaus, Michel (2008), "Component-Based Structural Equation Modeling", Total Quality Management \& Business Excellence, Vol. 19, No. 7-8: 871-886.

Terawatanavong, Civilia; Whitwell, Gregory J.; Widing, Robert E.; O'Cass, Aron (2011), "Technological Turbulence, Supplier Market Orientation, and Buyer Satisfaction", Journal of Business Research, No. 64: 911-918.

Thomson, Ann Marie; Perry, James L. (2006), “Collaboration Processes: Inside the Black Box”, Public Administration Review, No. 6: 20-32.

TiM [Türkiye ìhracatçılar Meclisi] (2015), “Türkiye'nin ilk 1000 ihracatçı Firması 2014”, http://www.tim. org.tr/tr/ihracat-arastirma-raporlari-ilk-1000-ihracatci-arastirmasi.html, (Erişim: 01.10.2015).

TÜik [Türkiye İstatistik Kurumu] (2015), "Girişim Özelliklerine Göre Dış Ticaret İstatistikleri 2014", http://www.tuik.gov.tr/PreHaberBultenleri.do?id=18587, (Erişim: 17.04.2016).

TWB [The World Bank] (2017), “World Development Indicators: Merchandise Exports", https://data.worldbank. org/indicator/TX.VAL.MRCH.CD.WT, (Erişim: 23.12. 2017).

Ulaga, Wolfgang; Eggert, Andreas (2006), “Relationship Value and Relationship Quality: Broadening the Nomological Network of Business-to-Business Relationships", European Journal of Marketing, Vol. 40, No. 3-4: 311-327.

UNCTAD [United Nations Conference on Trade and Development] (2017), "World Investment Report 2017, Annex Table 2", http://unctad.org/en/Publications Library/wir2017_en.pdf, (Erişim: 23.12.2017).

Ural, Tülin (2009), "The Effects of Relationship Quality on Export Performance", European Journal of Marketing, Vol. 43, No. 1-2: 139-168.

USCB [United States Census Bureau] (2013), “Concentration Ratios", https://www.census.gov/econ/ concentration.html, (Erişim: 02.04.2016).

Velez, Maria L.; Sanchez, Jose M.; Florez, Raquel; Alvarez-Dardet, Concha (2015), "How Control System Information Characteristics Affect Exporter-Intermediary Relationship Quality", International Business Review, No. 24: 812824.

Venkatesh, Viswanath; Bala, Hillol (2012), “Adoption and Impacts of Interorganizational Business Process Standards: Role of Partnering Synergy", Informations System Research, Vol. 23, No. 4: 1131-1157.

Williamson, Oliver E. (1979), "Transaction-Cost Economics: The Governance of Contractual Relations", Journal of Law and Economics, Vol. 22, No. 2: 233-261.

Wilson, David T. (1995), "An Integrated Model of Buyer-Seller Relationships", Journal of the Academy of Marketing Science, Vol. 23, No. 4: 335-345.

Woo, Ka-shing; Ennew, Christine T. (2004), “Business-to-Business Relationship Quality: An IMP Interaction-Based Conceptualization and Measurement", European Journal of Marketing, Vol. 38, No. 9-10: 1252-1271.

Wu, Fang; Sinkovics, Rudolf R.; Çavuşgil, S. Tamer; Roath, Anthony S. (2007), “Overcoming Export Manufacturers' Dilemma in International Expansion", Journal of International Business Studies, No. 18: 283-302.

Zaheer, Akbar; McEvily, Bill; Perrone, Vincenzo (1998), “Does Trust Matter? Exploring the Effects of Interorganizational and Interpersonal Trust on Performance", Organization Science, Vol. 9, No. 2: 141-159.

Zaheer, Srilata; Zaheer, Akbar (2006), "Trust across Borders", Journal of International Business Studies, No. 37: 21-29.

Zucker, Lynne G. (1986), "Production of Trust: Institutional Sources of Economic Structure, 1840-1920", Research in Organizational Behavior, No. 8: 53-111. 